\title{
Gender, Ideologi dan Kekuasaan dalam Video VICE Indonesia yang berjudul Polemik Poligami di Indonesia: Analisis Wacana Kritis Norman Fairclough
}

\author{
Isnaini Nur Azizah \\ Magister Ilmu Linguistik, Fakultas Ilmu Budaya, Universitas Airlangga Surabaya \\ issisnaini@gmail.com
}

\begin{abstract}
Discourse is a part of communication that contains a though. The domination have a power to influence people to agree about the thoughs. Using the theory of Critical Discourse Analysis (CDA) by Norman Fairclough, this research reveals the domination of gender and the hidden ideology in video that uploaded by Vice Indonesia entitled" Polemik Poligami di Indonesia". From the video, it can be seen that there is gender domination during the polygamy because women are not considere to do and have not the power to be fair. Thus, the ideology of patriarcky is clearly seen when the men have a power over their child and wife. Men are able to propagandize their family's thoughs.
\end{abstract}

Keywords: Cda; ideology; Norman Fairclough; polygamy.

\section{Intisari}

Wacana adalah bagian dari komunikasi yang tanpa disadari mengandung suatu pemikiran. Pemikiran yang dominan dalam wacana mempunyai kekuatan dalam mempengaruhi seseorang untuk setuju mengenai pemikiran tersebut. Dengan menggunakan teori analisis wacana kritis yang dirumuskan oleh Norman Fairclough, penelitian ini mengungkap dominasi gender dan ideology yang terselubung pada video yang diunggah oleh Vice Indonesia yang berjudul "Polemik Poligami di Indonesia". Dari video tersebut dapat diketahui bahwa terdapat dominasi gender dimana praktik poligami hanya boleh dilakukan oleh laki-laki saja karena perempuan dianggap tidak mempunyai kekuatan untuk bersikap adil. Lalu, ideology patriarki terlihat jelas dimana laki-laki memengang penuh kekuasaan atas istri dan anaknya serta mampu mempengaruhi dan mempropaganda pemikiran keluarganya.

Kata kunci: Cda; ideology; Norman Fairclough; poligami.

\section{Pendahuluan}

Wacana adalah bagian dari komunikasi yang tidak lepas dari pemikiran yang dipikirkan oleh penuturnya. Selain itu, wacana juga merupakan bagian dari bahasa yang mempunyai makna dan mewakili serta menggambarkan suatu ide atau pemikiran khusus. Wacana adalah kesatuan antar bagian di dalam suatu bangungan bahasa. Dalam pembentukan wacana pada dasarnya merupakan bentuk dari pemberlakuan kekuasaan (Faucault 2000 dalam Darma 2013:103). 
Sebenarnya tanpa disadari, wacana menanamkan gagasan dan konsep yang mengandung kekuasaan. Gagasan dan konsep tersebut menjadi kekuatan yang dapat menggiring opini atau pendapat seseorang untuk setuju dan mengikuti gagasan yang terdapat pada konsep tersebut. Ketika gagasan dan konsep tersebut menjadi wacana yang dominan maka secara cepat wacana tersebut dapat berkuasa dalam pemikiran seseorang. Selain itu wacana juga dapat dipahami sebagai bentuk dari struktur social yang berhubungan dengan ideology (Ar 2015, 63). Ideologi yang dimaksud dalam konteks ini adalah sebagai gagasan, keyakinan dan nilai yang menetapkan dominasi dan posisi. Jadi dapat disimpulkan bahwa wacana dapat mengontrol, megarahkan dan meminta seseorang untuk melaksanakan sesuatu yang diinginkan.

Sejatinya semua wacana mengandung suatu ideology yang terselubung yang mampu menggiring konsep atau opini dari suatu permasalahan yang terkadang dianggap tabu bagi masyarakat. Ideologi adalah sebuah gagasan, keyakinan, dan nilai yang menetapkan dominasi atas kekuasaan dan posisi (Ar 2015). Dalam ideology gender ada beberapa ideology yang mengatur identitas, kedudukan, posisi seta tingkah laku antara perempuan dan laki-laki. Di Indonesia ada beberapa macam ideology yang mendominasi dalam kultur dan budaya dalam bermasyarakat yaitu ideology patriarki, ideology familialisme, ideology ibuisme, dan ideology bapak ibuisme (Darma 2013).

Ideologi patriarki adalah ideology yang mendominasi di masyarakat Asia tak terkecuali Indonesia. Idologi patriarki adalah kekuasaan atau dominasi yang dipegang erat oleh laki-laki. Selain itu ideology familialisme juga mendominasi di masyarakat Indonesia bahkan masyarakat kapitalis Inggris. Ideology familia adalah ideology yang mengkonstruksi peranan perempuan di dalam rumah tangga yang berkedudukan sebagai ibu rumah tangga, istri yang baik dan ibu yang baik (Bhasin 1996).

Pada masa orde baru juga terdapat ideology ibuisme yang merupakan ideology yang melegalkan tindakan apa pun yang diambil oleh perempuan demi kelurga atau kelompok tanpa mengharapkan kekuasaan atau imbalan. Selain itu juga terdapat ideology bapak-ibuisme yang menempatkan bapak sebagai sumber utama kekuasaan dan ibu sebagai perantara kekuasaan. Dari beberapa macam ideology gender tersebut berfungsi sebagai alat untuk mencapai tujuan atau kepentingan tertentu yang berujung pada dominasi. 
Salah satu hal yang masih dianggap tabu di masyarakat adalah poligami. Di Indonesia, praktek poligami masih dianggap tabu sehingga mayoritas para perempuan tidak setuju dengan adanya praktik tersebut. Mereka mengaanggap jika perbuatan poligami adalah perilaku yang kurang baik dan merugikan. Namun hal tersebut berbanding terbalik dengan kelompok yang setuju dengan praktik tersebut. Mereka yang setuju dengan adanya praktik poligami menganggap jika praktik tersebut adalah bagian dari agama dan secara sukarela mereka akan mencarika madu atau istri kedua untuk suaminya.

Salah satu wacana yang menggandung ideology terdapat pada video yang diunggah oleh VICE Indonesia yang berjudul "Polemik Poligami di Indonesia: Berbagi Surga". Video tersebut merupakan sebuah video documenter yang meliput keseharian seorang lakilaki yang mempunyai istri lebih dari satu atau yang biasa disebut dengan poligami. Pada video tersebut menyoroti perihal paraktek poligami yang dilakukan oleh suatu kelompok dan memaparkan pendapat ahli terkait pologami serta pendapat seseorang yang tidak setuju dengan adanya paktek poligami.

Di Indonesia isu menengai poligami masih dianggap tabu oleh mayoritas masyarakat. Banyak perdebatan dikalangan masyarakat mengenai praktek poligami. Sebagian besar masyarakat menolak dengan adanya praktik poligami. Mayoritas masyarakat Indonesia menganggap poligami adalah musibah untuk rumah tangganya. Namun ada juga beberapa kelompok masyarakat yang setuju dan mendukung dengan praktik tersebut.

Video yang diunggah oleh VICE Indonesia menunjukkan bahwa adanya adanya praktik poligami yang dilakukan oleh suatu kelompok tertentu. Dalam video tersebut menampilkan pendapat sekelompok masyarakat yang setuju dan mendukung dengan dilakukannya praktik poligami. Disisi lain, dalam video tersebut juga menampilkan seseorang yang menolak dengan dilakukannya praktik poligami. Tidak hanya itu saja, dalam video yang berdurasi selama 25 menit juga menunjukkan pendapat seorang wanita dari akademisi islam terkait dengan praktik poligami.

Tujuan dari ditulisnya makalah ini adalah untuk meneliti dominasi gender dan mengetahui ideology dalam wacana yang terdapat pada video yang diunggah oleh VICE Indonesia dengan menggunakan teori analisis wacana kritis yang dirumuskan oleh Norman Fairclough. Menurut Fairclough (dalam Ar 2015:63) menjelaskan bahwa analisis wacana dalam bentuk teks menunjukkan hubungan antara bahasa dan masyarakat. Analisis wacana 
Fairclough mendasarkan pada hubungan antara teks mikro dengan konteks masyarakat makro. Pada analisis Fairclough menghubungkan antara suatu model analisis wacana yang mempunyai kontribusi dalam analisis social yang nantinya akan membawa nilai ideology tertentu. Dalam analisis yang dirancang oleh Fairclough membuat suatu model analisis wacana yag didasarkan pada linguistic, pemahaman social dan politik dan secara umum yang diintergrasikan pada perbahan social sehingga sering disebut dengan model social change.

Focus dari analisis wacana kritis Fairclough adalah penggunaan wacana yang mengacu pada pemakaian bahasa sebagai praktik social. Jika ditinjau dari Pratik social, bahasa mengandung implikasi seperti wacana adalah bentuk dari tindakan seseorang yang menggunakan bahasa sebagai suatu tindakan untuk merepresentasikan dunia realita dan bahasa sebagai hubungan timbal balik antara wacana dan struktur social. Pada analisis Fairclough membagi analisis wacana dalam tiga dimensi yaitu teks (analisis teks secara linguistic), discourse practice (proses produksi dan konsumsi teks) dan social cultural practice (hubungan antara konteks) (Fairclough 2003). Focus analisis dalam penelitian ini adalah sudut pandang social cultural practice. Penelitian mengenai analisis wacana kritis selalu memfokuskan pada analisis sosiolinguistik yang menghubungkan antara aspek linguistic dan komunikasi social (Blomaert 2005). Dalam penelitian ini penulis hanya membahas poligami dari sudut pandang pelaku yang setuju dengan adanya praktek poligami dan mengaplikasikan dalam kehidupannya.

\section{Metode Penelitian}

Pada penelitian ini, penulis menggunakan pendekatan deskriptif kualitatif yang bertujuan untuk mengetahui lebih dalam ideology yang terkandung dalam video yang diunggah oleh VICE Indonesia yang berjudul "Polemik Poligami di Indoesia: Berbagi Surga". Digunakkannya video tersebut sebagai objek dari penelitian ini karena dalam video tersebut menunjukan adanya praktik poligami yang dilakukan oleh suatu kelompok. Isi dari video tersebut sangat menarik dan berbeda dari yang lain karena dalam video itu menunjukkan sekelompok minoritas masyarakat yang setuju dengan dilakukannya praktik poligami dan kehidupan satu keluarga yang menjalani praktik poligami. Karena seperti yang kita tau bahwa perdebatan mengenai praktik poligami menuai banyak tolakan pada 
mayoritas masyarakat Indonesian. Namun pada video tersebut justru sebaliknya, mereka menerima dengan adanaya praktik poligami untuk tujuan tertentu.

Untuk menganalisi video tersebut penulis menggunakan teori analisis wacana kritis (CDA) yang dirumuskan oleh Norman Fairclough yang berguna untuk memahami dan mendalami ideology yang tertanam dalam video tersebut. Dalam analisis wacana kritis, Fairclough berupaya untuk membangun suatu model analisis wacana yang mempunyai peranan dalam analisis social dan budaya sehingga dapat mengkombinasikan antara tradisi analisis tekstual yang selalu melihat bahasa dengan konteks yang lebih luas (Nugroho 2012). Analisis wacana kritis yang digunakan dalam penelitian ini adalah hubungan antara teks, ideology dan kekuasaan. Karena menurut Fairclough (2003) bahwa CDA berguna untuk menyelidiki hubungan antara social dan ideology yang mengeksplorasi bagaimana peristiwa social (teks), praktik soaial (urutan wacana) dan struktur social (bahasa) yang muncul dari beberapa elemen.

\section{Hasil dan Pembahasan}

Dalam video documenter yang diunggah oleh VICE Indonesia, pertama-tama video tersebut meliput dan menunjukkan suatu komunitas yang setuju dengan adanya praktik poligami. Sang reporter VICE Indonesia menggunjungi sebuah konferensi yang mendukung adanya praktek poligami dan dihadiri oleh seluruh anggota komunitas. Adapun anggota dari komunitas tersebut adalah sepasang suami istri, duda, janda, pria dan wanita yang masih lajang yang terdiri dari berbagai kalangan masyarakat. Diadakannya konferensi tersebut bertujuan untuk menjalin silaturahmi antar sesama komunitas. Pada saat konferensi tersebut terlihat founder dari komunitas memberikan sambutan dan materi setelah itu perkenalan anggota. Namun dibalik itu semua, sebenarnya dalam konferensi tersebut ingin menyampaikan suatu konsep mengenai poligami.

Konsep yang yang ingin disampaikan oleh founder dari konferensi tersebut bertujuan untuk mempropaganda anggotanya. Dalam konferensi tersebut founder yang sekaligus sebagai pengisi materi menjelaskan mengenai hukum dan syariat poligami. Beliau menjelaskan bahwa sebenarnaya poligami itu dianjurkan oleh agama untuk menjadi seorang muslim yang beriman untuk mencapai surganya. Hal tersebut dapat dilihat dalam potongan ucapan dari anggota komunitas tersebut yang terdapat pada menit ke 1:31" yaitu:

\section{A: "InsyaAllah sih cita-cita pengennya istrinya empat pak, karena sebaik-} baiknya manusia yang istrinya paling banyak". 
B: "Di akhir zaman ini paling besar fitnah itu dari wanita. Saya ingin menyelamatkan aqidah keluarga saya".

C: "Mohon doanya mudah-mudahan keluarga kami bisa sampai ke surga".

D: “Adanya KB (Keluarga Berencana) itu ajaran-ajaran dari orang di luar Islam agar umat Islam itu sedikit. Makanya kita lawan dengan adanya poligami untuk memperbanyak umat islam".

E: "Saya adalah istri dari pak N, motivasi saya sudah jelas. Saya datang kemari ingin mencarikan madu atau istri buat suami saya".

Dalam konferensi tersebut terlihat jika tujuan beberapa anggota komunitas yang datang adalah untuk mencari jodoh. Alasan beberapa pria yang datang yaitu mencari istri lagi sedangkan alasan beberapa wanita yang datang adalah untuk mencarikan madu (istri kedua) untuk suamianya. Hal tersebut diungkapkan oleh beberapa anggota konferensi saat ditunjuk untuk memperkenalkan diri dan menjelaskan motivasinya untuk datang dalam konferensi tersebut.

Sebenarnya tanpa kita sadari wacana yang dicetuskan dalam video tersebut mengandung suatu ideology yang tersembunyi. Ideologi yang terkandung dalam video yang diunggah oleh VICE Indonesia yang berjudul "Polemik Poligami di Indonesia: Berbagi Surga" adalah ideology patriarki. Patriarki adalah sebuah system social yang menempatkan laki-laki sebagai pemegang kekuasaan yang dominan dan utama dalam kepemimpinan, salah satunya kepada keluarga (Darma 2013). Dalam keluarga, laki-laki yang kedudukannya sebagai kepala keluarga mempunyai kuasa penuh atas anak dan istrinya. Dominasi kepala keluarga atas anak dan istrinya dapat mempropaganda seorang anak dan istri terhadap suatu pandangan mengenai pemikiran tertentu, salah satunya poligami. Dalam video tersebut juga menyorot aktifitas salah satu keluarga yang mendukung adanya praktik poligami. Dari aktifitas yang diliput tersebut dapat diketahui laki-laki yang kedudukannya sebagai suami mempropaganda perempuan yang berkedudukan sebagai istri mengenai pemikiran poligami.

Ketika reporter VICE Indonesia menanyakan kepada RR yang berkedudukan sebagai suami dan selaku pelaku praktik poligami mengenai hakikat dari dilakukannya poligami, dan RR menjawab dan menjelaskannya sebagai berikut:

RR: "Allah config manusia atau lelaki untuk kemungkinan menyukai lebih dari satu wanita, nah itu yang terjadi perselingkuhan ada gak? Yang jajan banyak gak? Itu bukti bahwa hakikatnya dorongan-dorongan (seksual) itu tidak 
dimunafikkan ada pada lelaki. Tapi disisi lain Islam memberikan jalan keluar yaitu nikah lagi”. (4.09”)

Dari penjelasan laki-laki tersebut dapat diketahui bahwa dia berusaha untuk mendoktrin seorang wanita bahwa Islam sangat menganjurkan laki-laki mempunyai istri lebih dari satu, karena pada hakekatnya seorang pria diciptakan oleh Allah itu mempunyai hastrat seksual yang tinggi daripada wanita. Jadi untuk menghindari perselingkuhan dan perzinahan di dalam Islam menganjurkan menikah lagi atau poligami.

Lalu pada video tersebut juga menunjukan hakikat dan tujuan dilakukannya poligami dari pandangan DW (istri kedua RR) yang terekam pada menit ke 7:28" yaitu:

DW: "Mengapa saya melarang (poligami) gitu, emangnya saya Tuhan. Gitulah. Karena bagi saya tidak ada kehinaan di dalam status itu (poligami), gak ada. Karena saya juga ada beberapa temen gitu yang cuhat suaminya selingkuh main perempuan, beberapa kali tapi dianya tetep mempertahankan rumah tangganya. Banyak ibu rumah tangga yang akhirnya tertular HIV AIDS karena suaminya sering jajan. Tapi kalau misalnya kembali lagi menjalur kepada apa yang telah ditetapkan Rabb kita Allah SWT, kerusakan-kerusakan itu tidak akan terjadi”.

Dari pendapat istri pertama dapat disimpulkan bahwa tidak ada yang salah dari dilakukannya poligami, karena DW menggangap bahwa poligami itu ketetapan dari Allah untuk menghindari hal-hal negative yang tidak diinginkan oleh umatnya. DW dapat mererima praktek poligami yang dilakukan oleh suaminya untuk menghindari beberapa hal yang tidak diinginkan seperti suaminya berselingkuh dan jajan diluar dengan wanita lain sehingga mengakibatkan tertularnya penyakit.

Propaganda yang dilakukan laki-laki dalam video ini terlihat sangat jelas. Dari cuplikan wawancara mengenai pendapat mereka tentang dilakukannya pratek poligami dari sudut pandang RR dan DW, mereka mempunyai pendapat dan pandangan yang sama. RR dan DW berpendapat poligami itu bukan suatu hal yang salah melainkan bahwa poligami adalah salah satu cara yang dilakukan untuk menghindari hal-hal yang tidak diinginkan dan dilarang dalam Islam seperti zina. Hal tersebut dapat dilihat dlam cuplikan ini:

RR: "Menyalurkan nafsu kepada istri adalah ibadah". (4:37”)

"Poligami itu tidak rusak". (14:40") 
DW: "Karena bagi saya tidak ada kehinaan dari status itu (poligami)”. (7:33”)

"Tapi kalau misalnya kembali lagi menjalur kepada apa yang telah ditetapkan Rabb kita Allah SWT, kerusakan-kerusakan itu tidak akan terjadi”. (7:55”)

Propanganda yang dilakuan oleh RR kepada dua istrinya, diakui secara terus terang oleh RR. RR berpendapat bahwa penanaman aqidah yang ditanamkan RR kepada dua istri dan anak-anaknya adalah kewajiban seorang suami. Hal tersebut bisa dilihat dari cuplikan berikut:

RR: "Bahwa memang tadi ada penanaman-penanaman aqidah yang membentuk presepsi itu satu keniscayaan yang itu memang tugas suami untuk membentuk istrinya. Tergantung kita mau menginstal program apa di kepala istri kita. Saya memutuskan bahwa saya, istri saya dan anak-anak saya harus diinstal dengan proram-program Islam”. (17:56”)

Dari cuplikan tersebut dapat dilihat bahwa laki-laki yang berkedudukan sebagai suami mempunyai kuasa penuh atas anak dan istrinya. Hal tersebut juga dijelaskan oleh RR secara jelas dan didukung dengan argument sang reporter bahwa:

Reporter: "RR seringkali mengandaikan istri-istrinya sebagai hardware computer yang siap di program. Ketika gua ngobrol dengan kedua istrinya RR selalu standby di sekitar kami. Beberapa kali gua mendengar istri-istrinya mengulang argumentasi yang sama persis seperti kata-kata RR”. (18:38”)

Selain itu laki-laki juga mempunyai peranan yang dominan dalam melakukan praktik poligami. Yang dimaksud dari peran dominan dalam konteks ini adalah hanya laki-laki yang boleh mempunyai istri lebih dari satu, sedangkan pada perempuan itu tidak berlaku dan hanya boleh memiliki satu suami saja. Dalam konteks pada paktek poligami hanya laki-laki yang boleh melakukannya karena laki-laki dianggap mampu berlaku adil kepada isri-istrinya sedangkan perempuan tidak mampu untuk melakukan keadilan seperti lakilaki. Jadi dapat disimpulkan bahwa hanya laki-laki yang bisa dan boleh memiliki istri lebih dari satu. Hal tersebut dijelaskan oleh keduanya, RM dan DW dengan statement sebagai berikut:

RR: "Karena pada faktanya kita pun harus realistis, kenapa? Karena perempuan itu lebih dominan perasaannya ketembang akalnya, lebih besar rasa cemburunya ketimbang logikanya". (5:04")

DW: "Perempuan dengan perasaannya itu lebih cenderung daripada akalnya, itu tidak akan tercapai keadilan". (8:53") 
Dan yang terakhir adalah statement istri kedua RR yaitu RM saat ditanya mengapa ia mau menjadi istri kedua adalah:

RM: "Di era sekarang ini susah banget nyari cowok yang agamanya bagus. ... Pertamanya sih ga nyangka ya dan ga pernah berpikiran buat jadi istri kedua juga. Tapi setelah ketemu sama aa orangnya baik agamanya bagus terus diyakinin juga sama teteh yang membuat saya yakin membuat saya untuk berpoligami. ... Poligami mungkin saling membantu dalam urusan anak dan keluarga. ... Kalau ngeliat dari sisi orang mah gak akan pernah ada habisnya, mau niatnya baik mau gimana pasti diomongin terus. Ya santai aja sih, uda nyarinya ridho Allah bukan ridho oranglain". (15:56”)

Dari statement yang dilontarkan oleh istri kedua $\mathrm{RR}$, RM rela dipoligami dan menjadi istri yang kedua karena RM ingin memiliki suami yang baik dan memiliki pengetahuan agama yang bagus. Selain itu alasan RM mau dipoligami karena RM ingin mencari rido Allah dalam pernikahan tersebut.

\section{Simpulan}

Pada penelitian ini penulis berusaha untuk mengungkap ideology yang terkandung pada video yang diunggah oleh VICE Indonesia yang berjudul Polemik Poligami di Indonesia: Berbagi Surga adalah ideology patriarki yang mana laki-laki yang berkedudukan sebagai suami pempunyai peranan yang dominan. Dalam video tersebut dapat diketahui bahwa hanya laki-laki yang boleh memiliki istri lebih dari satu, sedangkan perempuan tidak boleh. Selain itu laki-laki lebih dominan untuk mengontrol dan mempropaganda wanita. Hal itu dapat dilihat dengan adanya konsep dan pandagan yang sama mengenai poligami antara suami dan kedua istrinya. Pandangan pemikiran poligami yang tersirat dalam video tersebut adalah poligami sebagai perintah agama agar terbebas dari perzinahan seta mencari ridho Allah untuk mencapai surganya. Jadi dapat disimpulkan bahwa dalam praktek poligami didominasi oleh gender yang terlihat secara jelas dan sangat berperan dalam mempropaganda pemikiran.

\section{Daftar Pustaka}

Ar, Mustafa. "Language and Ideology in Text on Globalization: A Critical Discourse Analysis." Intrnational Journal of English Linguistics, Vol. 5, No. 2, 2015: 63-77.

Bhasin, K. Menggugat Patriarki: Pengantar tentang Persoalan Dominasi terhadap Kaum Perempuan. Yogyakarta: Bentang dan Kalyanamitra, 1996.

Blomaert, J. A Critical Introduction. Cambridge: Cambridge University Press, 2005. 
Darma, Yoce Aliah. Analisis Wacana Kritis. Bandung: Yrama Widya, 2013.

—. Analisis Wacana Kritis. Bandung: Yrma Widya, 2013.

Fairclough, N. Analyzing Discourse; Tekxtual Analysis for Social Research. New York and London: Routledge, 2003.

Fakih, M. Analisis Gender dan Transformasi Sosial. Yogyakarta: Pustaka Pelajar, 1999.

Polemik Poligami di Indonesia: Berbagi Surga. Directed by VICE Indonesia. 2018.

Mosse, J.C. Gender dan Pembangunan. Terjemahan Silawati dan Rifka Annisa. Women Crisis Centre. Yogyakarta: Pustaka Pelajar, 1996.

Nugroho, Agung Suryo. "Analisis Wacana Kritis terhadap Iklan-Iklan Pajak dalam Pembentukan Realitas pada Kehidupan Masyarakat." Ranah, Vol.1, No.1, 2012: 56-70. 